\title{
Opposition "Universal and Specific Names of Coffee" as a New Communication Trend
}

\author{
Mukhina Irina', Efremovskikh Anastasia² \\ ${ }^{1}$ Ural Federal University, Ekaterinburg, Russia \\ 2 Ural Federal University, Ekaterinburg, Russia \\ Corresponding author: Mukhina Irirna, i.k.mukhina@urfu.ru
}

\begin{abstract}
The purpose of the article is to summarise the results of a psycholinguistic experiment based on a thematic analysis of associative reactions to universal and specific coffee names, as well as to identify their frequency spelling and orthoepic variants. The psycholinguistic experiment clearly showed how the process of coffee names assimilation as borrowed words in Russian is continuing and which images arise in native speakers' minds when using them. It has been revealed that in the consciousness of modern Russian native speakers, the tendency to contrast universal and specific names of coffee is manifested. Universal coffee names have already passed the process of borrowing, the regulatory form of specific coffee names is currently absent both in explanatory dictionaries and in unofficial use, so the most common orthoepic and spelling variants can be considered those that are familiar and convenient for Russian native speakers. The universal and specific names of coffee beverages function as a new communication trend in the life of modern young people.
\end{abstract}

Keywords: psycholinguistic experiment, semantic associations, realities, orthographic variants, orthoepic variants, relations of the opposite

\section{Introduction}

This study is devoted to the problem of adopting coffee names as borrowed words by the Russian language, and to identifying ideas about their meaning in the minds of Russian native speakers.

Each culture has its characteristics and traditions, and therefore members of other ethnic communities look at their behaviour through their views, national differences and ethnic stereotypes. Internationalisation leads to the borrowing process, as some words have no equivalent in their native language, as they do not correspond to the reality of the national culture borrowing them. Authoritative researchers of realities I. Markovina and Y. Sorokin 
note: "Everything that the recipient has noticed in a foreign cultural text, but does not understand what seems strange and requires interpretation, serves as a signal of the explicit presence in the text of national specific elements of culture in which the text was created" [Markovina and Sorokin, 1989, 35]. Borrowings are not only a way of enriching the vocabulary, but they are also changing according to the phonetic and grammatical characteristics of the recipient language.

Today, various types of coffee beverages have become available to consumers, which, like the coffee lexeme itself (in Russian, кофе), are usually indeclinable nouns in the Russian language. G. O. Vinokur, M. V. Panov and other scientists have expressed the opinion that the growth of indeclinable nouns is a confirmation of the Russian language's tendency towards analytics. A. V. Zelenin identifies various thematic groups of indeclinable nouns on a semantic basis [Zeleninand Vakhtola, 2008]. In his opinion, the central contradiction in the group of indeclinable nouns is the opposition of the literary norm and the actual word usage: from the point of view of the norm, since indeclinable nouns are "frozen lexical units" [Ibid., 2008, 94].

Leonid P. Krysin singles out a particular group of borrowings - exoticism as the names of national dishes and drinks [Krysin, 2007, 84]. Exoticism, even if the signs of a foreign language are preserved, can signify the reality that is inculcated in the recipient language. Some of the exoticism loses the semantic component that points to national specificity by going beyond the geographical boundaries of one language. Borrowed names of various types of coffee also represent exotic realities, which, by their very name, indicate the national identity of the people. Vereshchagin and Kostomarov introduce the term "semantic segments" - "elementary concepts within a general concept denoted by the word" [Vereshchagin and Kostomarov, 1980, 134]. The cultural and national specificity of the word semantics is reflected in the part of the semantic segment of the linguistic background. According to scientists, the linguistic background of a word reflects the connection between extralinguistic facts and reality phenomena, forms the associative connections of the word and determines the place of the word in the lexico-semantic field. The linguistic background is "a way of existence of public consciousness, a way of fixing extralinguistic facts mainly on the ordinary, mass and traditional level of its expression" [Ibid].

The linguistic background of a word is two-sided since it combines social and individual aspects. From the point of view of communication needs, 
the linguistic background indicates the boundaries of word compatibility. Formed in metalanguage communication, the lexical background influences changes in syntagmatic and paradigmatic semantic connections. When certain information is given to a person in the communication process, the individual vocabulary is modified, and new semantic parts are added to it, forming the semantics of the words of the second participant in the communication act. The formation of a new lexical background leads to the inclusion of new national and cultural semantic segments in semantics [ibid]. It can be argued that the lexemes of coffee drink names have an extended lexical background, which is formed by modifying the semantic segments in the act of communication.

The semantic segments included in the linguistic background of a word can be identified through the lexicographical interpretation of word meanings the names of coffee in explanatory dictionaries, as well as through survey and associative experiment data. Therefore, the methodological basis for this study was the achievements of the psycholinguistic direction in linguistics, which allow identifying the psycholinguistic meaning of a word as an ordered unity of semantic components that are associated with this sound shell in the minds of native speakers [Sternin, 2010, 58]. Researchers describe the psycholinguistic meaning of the word in several stages: summarization of the results of the vocabulary definition analysis required to obtain the initial list of values studied on the experimental material; description of the experiment, indicating the experimental material based on which the data are semantically interpreted; associative description of the semantics of a word, allowing its psycholinguistic content to be presented in a general manner; semantic interpretation of associative reactions, which consists of comprehending the obtained associative reactions as linguistic representations of values. The description of the psycholinguistic meaning of a word based on an associative experiment similarly makes it possible to present the meaning of a word as a phenomenon of the actual linguistic consciousness of native speakers.

Semantic associations are the subject of study in psychology (focusing primarily on the general analysis of semantic associations [Wang et al., 2019] and their role in the formation of declarative and procedural memory [Xie et al., 2019]), cognitive science in general (studying associations related to stimuli and reactions to them in the process of perception [Maayan Avneon, Dominique Lamy, 2019]; for instance, associations in the field of colour perception [Douglas Guilbeault et al., 2020]), linguistics (e.g. analysing the causes, results and consequences of changes in semantic associations 
influenced by bilingualism [Siqi Ning et al., 2020]), and cognitive linguistics (e.g. investigating changes in the development of association strength [Tai-Li Chou et al., 2019] and categorical connection to semantic brain processing.

\section{Methodology}

\subsection{Research material}

The object of the study is coffee names in Russian. The relevance of the study is determined by the need to analyse coffee names in Russian from a psycholinguistic perspective. The research material is as follows: 1) universal and specific coffee names; 2) answers-reactions to questions in the psycholinguistic experiment questionnaire; 3) lexical meanings of the names under investigation in Russian and English dictionaries.

The subject of the study is an analysis of the associative connections of lexemes, which are names of coffee. The analysis aims to conduct a psycholinguistic experiment, identify associative links between universal and specific names of coffee in the consciousness of Russian native speakers, and establish spelling and orthographic variants of their use.

2.2. Methods and stages of research

The study was conducted in several stages.

Stage 1. Form a questionnaire to conduct a psycholinguistic experiment.

Stage 2. Conduct a survey of informants with the help of the Internet.

Stage 3. Classify respondents' reactions to coffee names.

Stage 4. Analyse the results of a psycholinguistic experiment: to conduct a comparative analysis of reactions to universal and specific coffee names.

Stage 5. Form thematic groups of associations.

Stage 6. Identify frequency and spelling variants of universal and specific names of coffee as well as variants that can be considered regulatory.

Methods of component and contextual analysis, vocabulary definition analysis and psycholinguistic experiments were used.

\subsection{Description of a psycholinguistic experiment}

The aim of the experiment: the psycholinguistic experiment should show how the process of assimilating coffee names as borrowed words in the Russian language is progressing and reveal the specifics of reflecting the semantics of different coffee names in the minds of Russian speakers.

The questionnaire consisted of 20 questions, which can be divided into the following groups. 
1. Questions that give an overview of the respondent (gender, age, education, academic and professional specialisation).

2. General questions to determine how familiar the respondent is with the 'culture of coffee consumption' (how often he or she goes to coffee shops, his or her favourite drink, what he or she orders most often, whether the concept of $a$ barista is familiar to the respondent, how price influences the choice of drink.).

3. Questions that reveal direct associative reactions to stimuli the names of universal coffee names (associations about the words coffee, barista, cappuccino, americano, latte, espresso), for example, what associations do you have when you think about coffee? Write between 1 and 10 words (different parts of speech can be written) or phrases. Who is a barista? What kind of associations does this word evoke? What kind of associations do you have with the words cappuccino, espresso, latte and americano? (write the reactions to each word individually). The questions of the first, second and third group characterise the associative chain experiment with free choice of answers.

4. Questions that reveal respondents' knowledge and assumptions about the etymology of universal coffee beverages (e.g. the etymology of the word espresso), as well as specific features: e. g. the difference between cappuccino (капучино) and latte (латmе), the difference between americano (американо) and espresso (эспрессо).

5. Questions aimed at determining respondents' knowledge of spelling and orthoepic variants of universal coffee names (evaluation of four variants of spelling of the lexeme cappuccino, the question about stress in the word latte).

6. Questions aimed at identifying the level of respondents' familiarity with specific names of coffee (which 'exotic' drinks are known to the respondent; whether the respondent is familiar with coffee names such as raf (in Russian, "paø-кофе") flat white, glasse and frappé; and clarification of the etymology of bumble coffee).

7. Questions aimed at determining respondents' knowledge of orthoepic variants, which indicate peculiarities of the pronunciation of specific names such as flat white coffee, glace coffee (in Russian, глясce) and mocha (in Russian, мокко).

A total of 103 respondents, aged 15 to 58, took part in the linguistic experiment, with the majority (66) being Russian-speaking students in the humanities (51). Four respondents refrained from specifying their specialisation. Questions that give an idea of the respondent are of the type 
used in a given experiment (since questions about the gender of respondents have two options) and in a free experiment (for example, questions about the respondent's education and specialisation). Among 103 respondents, 84 were female, and 19 were male.

\section{Results}

\subsection{Typology of coffee names}

Two groups can be distinguished by the extent to which coffee is consumed: the universal names of coffee varieties used by all restaurants and the specific names of coffee-based drinks, which are specific to certain restaurants. Universal names of coffee include a basic coffee drink, the names of which are known to most native Russian speakers - cappuccino (капучино), latte (латте), americano (американо) and espresso (эспрессо). Specific names of coffee, based on the results of monitoring of coffee maps of catering establishments in Ekaterinburg, include glasse (гляссе), mосhассіпо (тосһа) (мокачино - мокко), raf (раф), frapриссіпо (фраппучино), bumble (бамбл) and flat white.

According to Zelenin's classification of indeclinable nouns, the "Dishes and Drinks" thematic group is the fourth most frequently used in the explanatory dictionaries, with most words in this thematic group being borrowed from French into Russian and a small number (e.g. espresso) from Italian. All universal coffee names were borrowed from the Italian language, and all of them received lexicographical interpretation in Russian dictionaries. The difficulty in studying the semantic content of specific coffee names is that Russian language dictionaries do not always include these lexemes.

Espresso (эспрессо), americano (американо), сарриссіпо (капучино) and latte (латте) lexemes come from the Italian language. The lexeme raf ( of the Moscow coffee shop visitor after whom the coffee was named) or the English word rough. Glasse (глясе), mосhа (мока) and frappиссіпо (фраппучино) are of French origin, and bumble (бамбл) is of English origin. Thus, most coffee titles (4 lexemes) came to Russian from Italian, three from French and two from English.

The names of coffee are, by their type, realities, i. e. "words and phrases that call objects specific to the life of one nation and foreign to another" [Vlahov, $1980,45]$. Realities carry national or historical connotations and generally do not have exact equivalents in other languages [Ibid]. Scientists offer a typology 
of realities on various grounds. Using the principles of this classification, it is possible to identify the specifics of different coffee names. In terms of prevalence and usability, the reality may be national and local, with names belonging to a particular people referring to national realities (e.g. Italian espresso).

From the point of view of subject division, coffee names belong to ethnic realities, as Sergei I. Vlahov and Sider P. Florin believe that all the names of dishes and beverages belong to ethnic realities. By nationality of the object denoted by the reality of the object and by the specifics of the languages involved in the translation, the names of coffee can be considered foreign realities, as they are borrowed words. Coffee names are international realities: they preserve their original national identity but appear in the vocabulary of many languages as part of the explanatory dictionaries and dictionaries of foreign languages. In terms of specifics of translation, the names of coffee beverages as realities are internal to the "language of origin (Italian, French, English) - Russian" pair.

3.2. Analysis of the results of a psycholinguistic experiment

3.2.1. Statistical analysis

According to the results of the quantitative analysis of the questionnaire's answers, among 103 respondents, 56 rarely go to coffee shops, 43 often do, and four do not go to coffee shops at all. Based on a scale of 1 to 5, the impact of price on beverage choice was insignificant - most respondents chose number 3 .

The cappuccino was the respondent's favourite drink (36 people), while ordinary supplements to this coffee, such as syrup or cinnamon, were not specified, and latte (33 people). When choosing a latte, respondents were asked to clarify: the choice of respondents may be either matcha latte (in Russian, матча/маття латте) - a green coffee drink based on a matcha powder or latte macchiato (in Russian, латте макиато) - a milk and coffee cocktail consisting of three layers - milk, coffee and milk foam.

\subsubsection{Lexicographical analysis of "exotic" coffee beverages}

Matcha latte (матча/маття латте) - a green coffee drink based on a matcha powder [Tea website, 2014]. Etymology: matcha means "rubbed tea" in Japanese [Ibid]. Spelling and orthoepic variants: there are no spelling variants in Russian, but there are two variants of the pronunciation of this lexeme. There are no specific orthoepic rules for spelling this coffee name, but it is possible to write according to both the Japanese pronunciation rules маття латmе - and the European pronunciation - матча ['mætf.ə] 
[Cambridge Dictionary, 2020]. No lexicographical description of the lexeme is presented in the Russian dictionaries.

Latte macchiato (латте макиато) - a milk and coffee cocktail consisting of three layers - milk, coffee and milk foam. Etymology: in Italian latte macchiato means "stained milk" [Coffee website, 2020]. Spelling and orthographic variants: the name includes one row of doubled consonants [Cambridge Dictionary, 2020]; in foreign languages, with the Latin alphabet there is a single spelling. In Russian, the name coffee has two spelling variants, with the same pronunciation - without long consonants. First variant. The most frequent variant - макиато (macchiato) - is used by respondents in their answers to the questionnaire and is implemented in 3 contexts of use in the Russian National Corpus (e.g: Для обеда время еще раннее - всего одиннадиать утра, но пара столиков уже занята, за одним воркует парочка лет семнадиати-восемнадиати, за другим толстый дядька пьет из высокого стакана кофе макиато и читает что-то на планшетнике. А. Маринина ) [Russian National Corpus]. The second variant - маккиато (macchiato) - is not used in National Corps contexts. It can be argued that direct borrowing with two rows of doubled consonants was not adopted in the Russian language and it has adapted to the rules of Russian spelling. However, Italian is characterised by the doubling of consonants, which is why, using the "маккиато" variant, native Russian speakers are oriented towards the norms of the Italian language.

Raf (paø) coffee (was mentioned by 11 respondents) also became less popular; 5 people chose americano (американо), and 4 chose mocha (мокко). Coffee drinks, such as flat white and frappé (фpanne) were chosen twice.

In our opinion, the question of the ratio between the popularity of the drink and the stage of its assimilation in the Russian language is relevant. For example, cappuccino and latte, as universal names found in all coffee charts, are chosen by the majority of respondents as their favourite beverages: not only the taste is essential here, but also its unofficial fixation, as such names are known to most Russian native speakers.

Raf coffee, when its inner shape is unclear, has been indicated as the favourite drink by 11 people, and in most cases, it is chosen by people who rarely

* Hereinafter the translation is provided in English: it is still early for lunch — it is only eleven o'clock in the morning, but a couple of tables are already busy, a couple of seventeen or eighteen years old cooing at one table and a fat man drinks from a tall glass of macchiato and reads something on his tablet (A. Marinina). 
visit coffee shops. It is possible since there are practically no external differences between cappuccino and raf coffee (for example, they are brought in a cup with the same volume of milk foam on top), but from a taste point of view, raf is much more likely served with syrup or cinnamon. When indicating their favourite drink, respondents did not describe the specifics of drinking cappuccino but noted that they ordered raf with some kind of syrup, cinnamon or halva.

2.4. Analysis of associative connections

2.4.1. General quantitative analysis of the associations received

Respondents were asked questions aimed at identifying direct associative reactions to stimuli - the names of universal coffee names. For each lexeme, not only words were presented as reactions, but also word combinations. A total of 93 associations related to the lexeme americano were identified, 43 of which are paradigmatic and 50 syntagmatic. The lexeme espresso has 104 associations, 45 of which are paradigmatic and 59 syntagmatic. The survey identified 101 associations related to the universal name of cappuccino, 69 of which are paradigmatic and 32 syntagmatic. Latte coffee has 103 associations, where 57 of which are paradigmatic and 46 are syntagmatic.

Thus, there are 906 associations in total. A more significant number of paradigmatic associations are found in the lexemes of cappuccino and latte, while the lexemes of espresso and americano are predominantly syntagmatic. Further analysis of associative relationships makes it possible to identify the reasons for this pattern.

\subsubsection{Analysis of associative connections of universal coffee names}

Let us consider as an example the analysis of reaction group associations received from respondents to the stimulus americano compared to associations on the lexeme cappuccino (quantitative indicators are given in brackets).

The espresso association set includes nouns such as vivacity, bitterness, strength and fastness. In our opinion, this can be explained by the fact that a cup of espresso is, in the consciousness of Russians, an attribute of a business person, which is why it is associated with the classic style of clothing or office. This may be due to the frequency of the visual broadcast from espresso to the mass media, where people in a hurry to work only have time in the morning for a small cup of coffee.

Espresso is coffee that is made very quickly and under high pressure, using the press, hence its name. Several respondents ( 21 people) proposed a theory about the origin of the word espresso from the Italian language. Several variants of the origin of the name espresso from the lexeme express (10 answers), 
associated with speed, power and speed were also presented. Espresso is a type of coffee that is prepared very quickly, so in the consciousness of Russian native speakers, as a result of the process of folk etymology as a false lexical association, an associative sequence is formed: espresso - express. The new espresso borrowing is distorted and reinterpreted on the model of the previously borrowed and already mastered by native speakers of the Russian language, which is similar in sound to the word express.

The associations make it possible to identify taste differences between espresso and americano. According to the respondents, espresso is more robust (the robust association is found in 29 reactions), is not diluted with boiling water (18 reactions contain the idea americano is espresso diluted with boiling water), is served in small cups (the lexeme volume is found in 15 reactions) and is considered more concentrated (concentration - 9 reactions) than americano.

Analysis of reactions to universal coffee names has shown that all of them are well fixed in the consciousness of native Russian speakers, who understand the difference in the preparation and serving of drinks. Grammatically, the names associated with these names are usually adjectives indicating the taste of the drink.

2.4.3. Spelling and orthoepic variants of universal coffee names

Cappuccino has four spelling variants in Russian, with the same pronunciation - without long consonants. Based on the results of the linguistic experiment, we will consider these options in more detail based on the frequency index. The first frequency option - капучино — was chosen by 87 people. In the Russian National Corpus, this version is the second most common. "Spelling Dictionary" edited by Vladimir V. Lopatin [Lopatin, 2000] and "Modern Explanatory Dictionary of Russian Language" by Tatiana F. Efremova [Efremova, 2006] allows only one variant of spelling - капучино. The second most frequently chosen option is капуччино (selected by 11 people). In the Russian National Corpus this option is implemented in 63 contexts, for example: Передо мной капучиино с корицей, бабушка взяла себе чашечку эспрессо* (К. Крылов). The third option is каппучино, which has been chosen nine times. It occurs 16 times in the Russian National Corpus; for example: Какой кофе пьет девушка? - Каппучино. - Так я и думал ${ }^{* *}$ (Е. Козырева). The fourth option - каппуччино- was the least

I was looking at a cinnamon cappuccino, and my grandmother took a cup of espresso (K. Krylov).

What kind of coffee does a girl drink? - Cappuccino. - This is what I thought (E. Kozyreva). 
common, chosen by 2 respondents. In the Russian National Corpus this lexeme is used four times, for example: <..> знаменитые бриочи, они же в моем понимании и круассаны, и кофе-эспрессо или каппуччино - все это на столе (А. Кучаев).

It should be noted that 5 people allow two spelling variants - капучино and капуччино (3 reactions), капучино and каппуччино (1 reaction), капучино and каппучино (1 reaction). Lexicographers also allow two spelling variants: Ekaterina N. Shagalova's "Dictionary of Newest Foreign Words" gives both spelling variants, and the etymology is derived from Spanish capuchino: Капуччино и капучино, нескл., м. Кофе с молоком и пышной

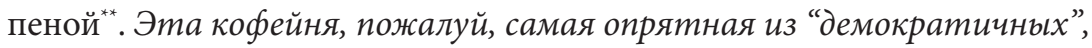
там забористьй эспрессо и "правильный" капуччино. (АиФ-Москва, 26.09.01) ${ }^{* * *}$. Etymology: from Spanish Capuchino [Shagalova, 2017].

Thus, it can be argued that the Russian language has not directly borrowed a lexeme with two rows of doubled consonants (каппуччино), it has adapted to the traditions of Russian spelling, as evidenced by the associative reactions of native speakers. The Italian language is characterised by the doubling of consonants, which is why native speakers of Russian use the каппуччино variant.

Let us look at orthoepic variants of the word latte. There is currently no fixed standard pronunciation in Russian, and the name coffee is rarely found in dictionaries. On the one hand, latte is a coffee drink from Italy; latte, translated from Italian as "milk", is pronounced in Italian with stress on the first syllable. On the other hand, in coffee shops that position themselves as French, waiters have a standard pronunciation with an accent placed on the final syllable according to French rules of pronunciation. In the "Spelling Dictionary", edited by Vladimir V. Lopatin [Lopatin, 2000], the only variant has an emphasis on the first syllable. The Cambridge Dictionary [Cambridge Dictionary, 2019] also supports this emphasis in both the British and American versions of English: UK ['læt.eI], US ['la:.ter].

Of the 103 people surveyed, only 3 chose the orthoepic version of the latté, which meets French pronunciation standards with an accent on the last

${ }^{*}<\ldots>$ the famous brioches, they are also croissants, and espresso or cappuccino - all this on the table (A. Kuchaev).

** Cappuccino, indecl., masculine. Coffee with milk and thick foam.

*** This coffee shop is probably the tidiest of the "democracies", with fenced espressos and the "right" cappuccino. (AiF-Moscow, 26.09.01). 
syllable. All other respondents pronounce the word with an accent on the first syllable according to the rules of the Italian language. As a rule, pronunciation with the accent on the first syllable is explained by the fact that this option is more familiar to Russians (17 reactions), it is heard more often in coffee shops (7 reactions), this is what the barista says (5 reactions), and therefore this word is more comfortable and more convenient for Russians to pronounce with the accent on the first syllable.

Thus, there is no explicit confirmation as to which of the two options is more standard. Based on the results of the research, dictionary entries of explanatory dictionaries and dictionaries of borrowed words, it can be concluded that the option of latte with an accent on the first syllable can now be taken as standard.

\subsubsection{Association connections of specific names of coffee}

Specific names of coffee presented in the survey include glasse (гляссе), тосhассіпо (мокачино/мокко), raf (раф), flat white, frappuccino (фраппучино) and bamble (бамбл). The difficulty is that Russian dictionaries do not always include these lexemes. 67 out of 103 respondents are familiar with these specific lexemes, 32 have heard or seen such lexemes in the menu, and four respondents are not familiar with these lexemes. Based on the results of the survey, it can be concluded that specific coffee names are gradually becoming fixed in the use of modern Russian native speakers, as well as in the practice of their daily existence.

Among other "exotic" coffee drinks, the respondents included the following names that were not included in the list of words-stimuli of the questionnaire: coffee with sprite, green coffee (this is probably the name given to the relatively new matcha latte that has appeared in coffee shops), Irish coffee (coffee with whiskey), hot coconut crème (raf coffee on coconut milk with agave syrup and freeze-dried raspberries) [online magazine AfishaDaily, 2020], nitro coffee (cold-brewed coffee, saturated with nitrogen) [Coffee Magazine, 2020], ristretto (a variant of espresso, but smaller in volume, than espresso coffee, with less water) [Ibid], cold brew (cold-brewed coffee), affogato (espresso with an ice-cream ball), lungo (a variant of espresso that is larger in volume, less concentrated and lighter in taste) [The Village Internet newspaper, 2020], kopi luwak (coffee with aphrodisiacs). Thus, the "chart" of coffee beverages known to Russian-speaking respondents is quite extensive, perhaps because each coffee shop tries to include something original in the menu to attract customers. 
Bumble (бамбл) is a cold espresso-based coffee drink with the addition of caramel syrup, freshly squeezed orange juice and ice. According to Internet sources [Ibid], the name first appeared in Moscow in 2001: a coffee drink was named based on the abbreviation of the English word combination bumblebee ['bım.bəl.bi:] [Cambridge Dictionary, 2019] for its look: the drink is 'split' into two parts - a strip of orange - juice and a dark strip - coffee. The versions of the origin of this coffee beverage offered by respondents can be divided into several groups.

1) The internal form of a word is associated with the process of its making: with a sound imitation (14 reactions) - bumble - a sound that occurs when something is shaken (2 people); with an explosion (5 people); association bubble gum is based on the similarity in the pronunciation of the English lexemes bubble [bıb.əl] [Ibid] and bumblebee (5 people), as well as with stirring, some kind of hissing sounds. One possible reason for these associative connections may be orthoepic - the sound imitation arises from the sonorous sounds $[\mathrm{l}]$ and $[\mathrm{m}]$ in the word and the repetitive ringing sound [b].

2) The internal shape of the word is related to the appearance of the drink (50 reactions) - bubbles (21 people), a colour similar to that of a bumblebee (21 people), balloons ( 5 people), because bubble [b $\Delta$ b.əl] [Ibid] is 'ball', and foam (2 people), which is also referred to by associations such as whipped and bear. The association bear probably appeared by analogy with the colour of this animal: the colour of the bear's fur coincides with the colour of the coffee layer in the bumble coffee.

3) The internal form of the word bumble is related to the taste of the beverage (11 reactions), the following associations indicate this: a mix of different tastes (5 reactions), honey (3 reactions), fruity, creamy, sweet. Bumble coffee does not have fruit or honey; it mixes espresso and orange juice. It can be concluded that such false associative connections arise from a lack of knowledge about the composition of the beverage and how it is prepared.

Thus, more respondents believe that bumble has its name because of its appearance. However, there are equally frequent versions of the similarity of coffee to both bumblebees and bubbles. In the minds of Russian native speakers, an associative bumble - bubble set is built.

2.4.5. Spelling and orthoepic variants of specific names of coffee

Flat white is a coffee-based on double espresso with the addition of milk. No specific rules are defining the spelling and orthoepic norm of this coffee name in the Russian language. It is possible to write both in English - flat 
white, and as transcription in Russian - блэт уайm. The cyrillic transcription in the coffee shop menu is used so that visitors do not have trouble with pronunciation when ordering.

According to the results of the experiment, the majority of native Russian speakers (91 people) adhere to the фблэm yaŭm transcription variant. The second most popular option is фблэт вайm (10 people), which combines transcription (флээ) ) and transliteration (вайm). Three respondents accept the use of both the first and second version. One person chose the option of full transliteration - флат вайm.

The флэт уайmvariant is not found in dictionaries or the Russian National Corpus, so it is difficult to discuss the standard version. Based on the results of the study, it can be concluded that the блэт уайm variant can be taken as the more common at this stage of borrowing the word.

Glasse - a cold coffee drink with ice cream or whipped cream. In the Oxford Dictionary [Oxford Dictionary, 2019] the accent, perhaps similar to the English glass [gla:s], "glass, mirror" and falls on the first syllable ['glaser]. In the "Spelling Dictionary" edited by Vladimir V. Lopatin [Lopatin, 2000], explanatory dictionaries edited by Sergey A. Kuznetsov [Modern explanatory dictionary, 2001], T. F. Efremova [Efremova, 2006] has the only variant with the stress on the final syllable.

The survey has the question about the pronunciation; there are four versions in the Russian language — гля́c[э], гляс[э́], гля́c[e], гляс[é]. The first variant in terms of frequency ( 80 respondents) - гляс[э́] - is fixed in the "Explanatory Dictionary" edited by Sergey A. Kuznetsov: Глясе [сэ], неизм.; в зн. прил. [франц. glace - ледяной] . Кофе глясе. Холодный черный кофе с мороженым или со взбитыми сливками [Modern Explanatory Dictionary, 2001] $]^{* *}$.

Eighteen respondents accept the second option гля́с[э]. Four people permit гля́с [э] and гляс[э́] variants. Variants гляс[е́] (5) and гля́с[е] were the least used. Thus, by summing up the survey and dictionary information, it can be concluded that the гляс[э́] variant can be taken as standard.

Mocha (мокко) is a coffee drink with hot chocolate and milk [ibid]. At the moment, the explanatory dictionary edited by Sergey A. Kuznetsov [Ibid.] contains the standard of spelling of this word: Мокко, неизм.; м. и ср.

* Glasse, indecl.; in the meaning of the adjective [from French, glace - icy].

* Glasse coffee. Cold black coffee with ice cream or whipped cream. 
[франц. moka] $]^{*}$ 1. Сорт кофе; кофе этого сорта. Пить м.. 2 . Напиток из кофе с горячим шоколадом и молоком ${ }^{* * *}$.

According to Internet sources [Coffee Blog, 2019], three concepts may be worth distinguishing between Moha - a port in Yemen, mocha - a coffee variety, and mocha - a coffee drink.

Let us refer to information in the explanatory dictionaries. Cambridge Dictionary [Cambridge Dictionary, 2029] has mocha spelling and pronunciation as ['mok.ə]. The sound [ə] is pronounced in English in a European manner because the sound [a] at the end of the word is not pronounced as [a]. It is a difficult sound for native Russian speakers, pronounced as the middle between [a] and [e].

According to the survey, the vast majority of those surveyed (65 people) pronounce мокко[o], while the remaining 35 prefer мокк[a]. The second variant is closer to the European pronunciation, and the first variant corresponds to the pronunciation of a part of borrowed words with no reduction, such as $6[o] a, p[o] \kappa[o] \kappa o, m p u[o]$ and similar, in which the orthoepic rules allow for the utterance of a stress-free [o]. Thus, although there is no indication of the standard pronunciation of the word in the explanatory dictionaries, the мокк[o] variant can be considered the most common.

\section{Discussion and Conclusion}

The analysis of the results of the associative experiment made it possible to present the psycholinguistic meaning of words - names of coffee drinks - as a phenomenon of actual linguistic consciousness of modern Russian native speakers.

According to the received information, associative reactions were given to the lexeme coffee in 15 thematic groups; the most frequent of which are taste, colour, temperature (143 reactions), respondent's condition after drinking (65 reactions), ingredients ( 51 reactions), nature's condition, time of day (30 reactions). The most frequent associations for universal coffee names were adjectives and word combinations: cappuccino - milk foam (19 reactions), espresso - bitter (14 reactions), latte - coffee with milk (21 reactions), americano - unpleasant taste (12 reactions).

\footnotetext{
Mocha, indecl.; masculine and neutral [from French, moka].

* Coffee variety; coffee of this variety.

${ }^{* * *}$ A coffee drink with hot chocolate and milk.
} 
From the point of view of the existence of an extensive associative-verbal network related in the minds of Russian native speakers to coffee nominations, their frequency of use, the presence/absence of a system of orthoepic and spelling variants in explanatory dictionaries and the sphere of unofficial use, there is an opposition between universal and specific names of coffee. The existing opposition to universal and specific names of coffee can undoubtedly be considered a new communication trend, expressing the taste, smell, visual and other cognitive experiences of Russian native speakers by various modus means - from the complex communication of visual and verbal components in coffee cards and outdoor advertising of cafes to the organisation of associative-verbal networks in the mind. At the same time, new communication trends related to the variety of coffee beverages are being demonstrated by different cultural codes. For example, in the language cultural code, the names of coffee drinks are lexemes that have no equivalents in Russian, which, according to the classification of realities, belong to ethnic, foreign, international and internal realities and serve as a source of the above described creative, associative reflections in the consciousness, including those that form the multiculturalism of native speakers of modern Russian. Thus, borrowed words (хюгге / hygge, инди-групnа / indie band - musical genre) and neologisms (книжно / bookish, ламповость / atmospheric) often appear as reactions, because the respondents are young people who are familiar with current trends and are themselves trend creators.

The psycholinguistic experiment demonstrated how the process of assimilating coffee names as borrowed words in Russian is progressing and what images native speakers have when using these words. The analysis showed that universal coffee names have generally undergone the Russian language borrowing process. The linguistic experiment revealed that specific names are known to most respondents, but usually, they do not have a dictionary-based orthoepic and spelling standard form of usage, so the most common orthoepic and spelling variants are those that are familiar and convenient for native speakers of Russian, such as фолэт уайт, гляс[э́], мокк[о]. In the future, the results of the study may serve as practical information for solving controversial questions about the normative fixation in dictionaries of spelling, spelling and grammatical variants of coffee names as borrowed words in the Russian language. The practical significance of the study lies in the fact that its findings can be used in compiling explanatory and spelling dictionaries of the Russian language, dictionaries of the latest foreign words and associative dictionaries. 
Further prospects for work include expanding the audience of respondents, conducting a more detailed analysis of information from the associative experiment in various aspects, and studying the specifics of the functioning of coffee names in publicists and fiction texts.

\section{Acknowledgements}

The study was carried out with the financial support of the Russian Foundation for Basic Research in the framework of the scientific project No. 19-012-00458 "Relations of Identities and Opposites: Integration of Mental Spaces in Lexicographic, Structural-Semantic and Cognitive-Discursive Presentation", as well as the work was supported by Act 211 Government of the Russian Federation, contract № 02.A03.21.0006.

\section{Conflict of Interest}

The authors have no conflict of interest to declare.

\section{References:}

1. I. Y. Markovina, Y. A. Sorokin. Experience of systematization of the linguistic and extra-linguistic factors influencing the text understanding. Science, Novosibirsk (1989), pp. 103-184.

2. A. V. Zelenin. Indeclinable nouns in modern Russian. Linguistic notes, 1 (2008), pp. 59-65.

3. L.P. Krysin. Borrowed words as signs of other culture. Russian language at school, 4 (2007), pp. 83-87.

4. E. M. Vereshchagin. Modern Russian language: Lexicology, Phrazeology, Lexicography: Crestomatia and study tasks: Culture-oriented theory of a word. Faculty of Philology, St. Petersburg State University, St. Petersburg (2002), pp. 132-142.

5. I. A. Sternin. To development of the psycholinguistic explanatory dictionary. Problems of psycholinguistics, 12 (2010), pp. 57-63.

6. W. Songnan, C. Linjing, X. Junhai, Zh. Gaoyan, L. Baolin. Opinion mining from online travel reviews: A comparative analysis of Chinese major OTAs using semantic association analysis. Tourism Management, 74 (2019), pp. 276-289.

7. X. Ting-Ting, W. Tian-Ze, W. Yi-Ping, Y. En-Cheng. Declarative memory affects procedural memory: The role of semantic association and sequence matching. Psychology of Sport and Exercise, 43 (2019), pp. 253-260.

8. M. Avneon, D. Lamy. Do semantic priming and retrieval of stimulus-response associations depend on conscious perception? Consciousness and Cognition, 69 (2019), pp. 36-51. 
9. D. Guilbeault, E. O. Nadler, M. Chu Donald, R. Lo Sardo, A. Abubaker Kar, B. Srinivasa Desikan. Color associations in abstract semantic domains. Cognition, 201 (2020).

10. S. Ning, S. Hayakawa, J. Bartolotti, V. Marian. On language and thought: Bilingual experience influences semantic associations. Journal of Neurolinguistics, 56 (2020).

11. T.-L. Chou, C.-H. Wong, S.-Y. Chen, L.-Y. Fan, J. R. Booth. Developmental changes of association strength and categorical relatedness on semantic processing in the brain. Brain and Language, 189 (2019), pp. 10-19.

12. S. I. Vlakhov. Untranslatable in translation: monograph. International Relations, Moscow (1980).

13. Website about tea. https://teaonline.com.ua/istorija-chaya-matcha/ (Accessed 12 May 2020).

14. Cambridge Dictionary. https://dictionary.cambridge.org (Accessed 12 May 2020).

15. Website about coffee. https://vseprocofe.ru/napitki/latte-proishozhdenie-upotreblenie/ (Accessed 12 May 2020).

16. Russian National Corpus. http://www.ruscorpora.ru (Accessed 13 December 2019).

17. V.V. Lopatin. Russian Spelling Dictionary. Azbukovnik, Moscow (2000).

18. T.F. Efremova. Modern Explanatory Dictionary of the Russian Language. Astrel Publishment, Moscow (2006).

19. E. N. Shagalova. Dictionary of the newest foreign words. AST-PRESS, Moscow (2017).

20. Cambridge Dictionary. https://dictionary.cambridge.org (Accessed 04 February 2019).

21. Internet magazine AfishaDaily. https:/daily.afisha.ru/eating/10291-12-sogrevayuschih-i-neobychnyh-kofeynyh-napitkov/ (Accessed 14 May 2020).

22. Coffee Magazine. https://stoneforest.ru/look/allabout/kofe/nitro-kofe/ (Accessed 14 May 2020).

23. Internet newspaper The Village. https://www.the-village.ru/village/food/ true-or-false-food/323957-lungo-amerikano (Access 14 May 2020).

24. Oxford Dictionary. https://en.oxforddictionaries.com (Accessed 07 February 2019).

25. Modern Explanatory Dictionary of Russian Language. Norint, St. Petersburg (2001).

26. Coffee blog. https://coffee-expert.com.ua/rus/blog/kak_pravilno_moka_ mokka_ili_mokko.htm (Accessed 07 February 2019). 